This is the author's final, peer-reviewed manuscript as accepted for publication. The publisher-formatted version may be available through the publisher's web site or your institution's library.

\title{
Thermochemical pretreatments for agricultural residue ash production for concrete
}

Feraidon F. Ataie and Kyle A. Riding

\section{How to cite this manuscript}

If you make reference to this version of the manuscript, use the following information:

Ataie, F. F., \& Riding, K. A. (2013). Thermochemical pretreatments for agricultural residue ash production for concrete. Retrieved from http://krex.ksu.edu

\section{Published Version Information}

Citation: Ataie, F. F., \& Riding, K. A. (2013). Thermochemical pretreatments for agricultural residue ash production for concrete. Journal of Materials in Civil Engineering, 25(11), 1703-1711.

Copyright: () 2013 American Society of Civil Engineers

Digital Object Identifier (DOI): doi:10.1061/(ASCE)MT.1943-5533.0000721

Publisher's Link: http://ascelibrary.org/doi/abs/10.1061/\%28ASCE\%29MT.19435533.0000721

This item was retrieved from the K-State Research Exchange (K-REx), the institutional repository of Kansas State University. K-REx is available at http://krex.ksu.edu 


\title{
Thermochemical Pretreatments for Agricultural Residue Ash Production for Concrete
}

\author{
Feraidon F. Ataie ${ }^{1}$ and Kyle A. Riding ${ }^{1}$
}

\section{Abstract:}

Agricultural residue ash is known to be a very reactive source of supplementary cementitious material (SCM) for use in concrete. The influence of thermochemical pretreatments on the reactivity of agricultural residue ash (ARA) for use as an SCM was studied. It was shown that pretreatments are effective in partial removal of alkali metals and other impurities out of both wheat straw and rice straw leading to ARA with lower loss on ignition (LOI), higher internal surface area, and higher amorphous silica content than that of unpretreated ARA. It was shown that the ash alkali content correlated with the ash LOI and amorphous silica content. When used at a cement replacement rate of $20 \%$ by mass, pretreated ARA accelerated the hydration of cement paste samples while unpretreated ARA retarded the cement hydration. Pretreatments were found to increase ARA reactivity as measured by calcium hydroxide content reduction with time. ARA increased compressive strength of mortar samples by $25 \%$ when used as $20 \%$ replacement of cement in the samples. It was found that the calcium hydroxide content of paste samples and mortar compressive strength were correlated to the amorphous silica content of the ash.

\footnotetext{
${ }^{1}$ Dept. of Civil Engineering, Kansas State University, Manhattan, KS 66506
} 
Introduction:

The use of supplementary cementitious material (SCM) can reduce the energy and $\mathrm{CO}_{2}$

22

23

24

25

26

27

28

29

30

31

32 intensity of concrete. Natural SCMs have received increasing interest because of their high reactivity, low cost, and availability in some regions where other SCMs are not available. Agricultural residue ash (ARA) such as rice husk ash (RHA) and sugarcane bagasse ash have been championed as SCMs that can greatly enhance strength and durability of concrete (Salas, et al. 2009; Feng, et al. 2004; Nair, et al. 2006; Cordeiro, et al. 2006; Agarwal 2006; Tuan, et al. 2011; Sales and Sofia 2010). Other agro-biomass such as wheat straw (WS) and rice straw (RS) could be a potential source for SCMs with similar pozzolanic reactivity to RHA. The pozzolanic reaction is the reaction between a siliceous material and calcium hydroxide $(\mathrm{CH})$ under water to form a cementitious material, as shown in Eq. 1(Wanson, et al. 2009).

$$
\mathrm{CH}+\mathrm{S}+\mathrm{H} \rightarrow \mathrm{CSH} \quad \text { Eq. } 1
$$

Note: Oxide notation is used throughout this paper, $\mathrm{C}=\mathrm{CaO}, \mathrm{S}=\mathrm{SiO}_{2}, \mathrm{H}=\mathrm{H}_{2} \mathrm{O}, \mathrm{A}=\mathrm{Al}_{2} \mathrm{O}_{3}$, $\mathrm{F}=\mathrm{Fe}_{2} \mathrm{O}_{3}$.

The pozzolanic reaction kinetics is known to be affected by many factors such as ash mineralogy, surface area, and carbon content of the pozzolanic materials (Feng, et al. 2004; Wanson, et al. 2010).

Agro-biomass pretreatment processes can enhance ARA reactivity for use in concrete. Thermochemical pretreatment techniques, such as dilute acid, have been shown to improve pozzolanic reactivity by increasing surface area and amorphous silica content and decreasing carbon content of RHA (Feng, et al. 2004; Wanson, et al. 2009; Chandrasekhar, et al. 2006). In the biofuel industry, thermochemical pretreatment of lignocellulosic biomass has proven to be very effective hydrolysis process for ethanol production (Zheng, et al. 2009; Saha, et al. 2005; Kristensen, et al. 2008; Mosier, et al. 2005). The dilute acid pretreatments are effective in 
43 removal of some hemicellulose; breakdown, re-localization, and structure change of lignin; and

44 defibration/decrystallization of cellulose of the biomass cell wall. Pretreatment of agro-biomass

45 has been shown to improve combustion properties of biomass for use as a fuel as a result of

46 leaching impurities such as $\mathrm{Na}, \mathrm{K}, \mathrm{Ca}$, and Mg (Jenkins, et al. 2003). These metals decrease the

47 biomass melting temperature and promote the release of unwanted byproducts during

48 combustion (Jenkins, et al. 2003).

49 The pozzolanic properties of rice straw ash (RSA) and wheat straw ash (WSA) have been

50 examined by only a few researchers. WSA that has not been pretreated has been found to be

51 pozzolanically reactive when burned at $570{ }^{\circ} \mathrm{C}$ and $670{ }^{\circ} \mathrm{C}$ for 5 hours (Biricik et al. 1999). Al-

52 Akhras and Abu-Alfoul (2002) have reported that mechanical properties of autoclaved mortar

53 specimens were improved with by WSA made by burning wheat straw at $650{ }^{\circ} \mathrm{C}$ for $20 \mathrm{hrs}$. RSA

54 has been shown to improve mechanical properties of mortar and concrete specimens through a

55 pozzolanic reaction (Francisco et al. 2008). One study showed that rice straw pretreated with

56 hydrolysis could produce good quality ash for use in concrete, however no comparison with

57 unpretreated rice straw ash was made to quantify the benefits of pretreatment (El-Damatty and

58 Hussain 2007). The impact of thermochemical pretreatments on the RSA and WSA sensitivity to

59 burning conditions and subsequent reactivity in a cementitious system has not been studied.

60 Additionally, the mechanism by which pretreatments improve ARA pozzolanicity has not been 61 fully established.

62 This paper documents the effects of thermochemical pretreatments on the physical properties, 63 chemical properties, and reactivity of WSA and RSA in a cementitious system. Employing 64 several pretreatments techniques and burning conditions, this study attempts to examines the 65 mechanism(s) by which pretreatments enhance ARA reactivity. Distilled water (DW) and $0.1 \mathrm{~N}$ 
hydrochloric acid ( $\mathrm{HCl})$ were used to pretreat the biomass at $23^{\circ} \mathrm{C}, 50^{\circ} \mathrm{C}$ and $80^{\circ} \mathrm{C}$ for several

67 soaking durations followed by burning at $500^{\circ} \mathrm{C}, 650^{\circ} \mathrm{C}, 700^{\circ} \mathrm{C}$, and $800^{\circ} \mathrm{C}$. Loss on ignition

68 (LOI), internal surface area, and amorphous silica content of ARA were measured for these

69 ashes. Isothermal calorimetry, thermogravimetric analysis, electrical conductivity measurements,

70 and mortar compressive strength were used to quantify the ARA reactivity.

71 Materials:

72

73 mortar experiments. Wheat straw (WS) was purchased from Britt’s farm in Manhattan, KS and

Rice straw (RS) was obtained from Missouri Rice Research Farm, Glennonville, Missouri.

76 Reagent grade $\mathrm{HCl}$ was obtained and diluted to $0.1 \mathrm{~N}$ for use in the study.

77 Experimental methods:

Hydrothermal and thermochemical pretreatment methods were performed on the WS and RS

79 using distilled water (DW) and $0.1 \mathrm{~N} \mathrm{HCl}$. To pretreat the biomass, $250 \mathrm{~g}$ of biomass was

80 immersed in $3100 \pm 100 \mathrm{~mL}$ of the solution in a $4000 \mathrm{~mL}$ glass jar. The sample was stored

81 undisturbed at a constant temperature for the immersion period of interest. Three different

82 temperatures, $23^{\circ} \mathrm{C}, 50^{\circ} \mathrm{C}$, and $80^{\circ} \mathrm{C}$, were used to make ash for each pretreatment method which

83 will be referred to as $\mathrm{DW} 23^{\circ} \mathrm{C}, \mathrm{DW} 50^{\circ} \mathrm{C}$, and $\mathrm{DW} 80^{\circ} \mathrm{C}$ for the distilled water pretreatment at

$8423^{\circ} \mathrm{C}, 50^{\circ} \mathrm{C}$, and $80^{\circ} \mathrm{C}$ and $\mathrm{HCl} 23{ }^{\circ} \mathrm{C}, \mathrm{HCl} 50^{\circ} \mathrm{C}$, and $\mathrm{HCl} 80^{\circ} \mathrm{C}$ for the $0.1 \mathrm{~N} \mathrm{HCl}$ pretreatment at

$8523^{\circ} \mathrm{C}, 50^{\circ} \mathrm{C}$, and $80^{\circ} \mathrm{C}$, respectively. AR samples were immersed for $0.5,1,2,4,8$, and 24 hrs

86 before burning. Leachate samples were collected from two separate containers of pretreated AR

87 for each time and temperature. The $\mathrm{Mg}, \mathrm{Ca}, \mathrm{K}$, and $\mathrm{Na}$ concentration was measured using

88 atomic absorption spectroscopy (AAS) for each container. The Mg, Ca, K, and Na concentration 
was reported as the average concentration of the two containers. After pretreatment, the biomass was rinsed twice with distilled water and dried at $80^{\circ} \mathrm{C}$ for storage until burning. $200 \mathrm{~g}$ of

91 biomass was burned in each ARA batch made. A stainless steel cage with two wire mesh 92 shelves was used to hold the biomass during burning. A stainless steel pan was placed below the cage to catch any ash that fell through the mesh. A programmable electric muffle furnace was used to heat the samples to a predetermined temperature and hold time. Samples were heated to a laser diffractometer and BET nitrogen adsorption respectively. LOI of ARA was determined by measuring the mass loss after heating one gram of dry ARA (WSA or RSA) to $800^{\circ} \mathrm{C}$ for 3 hrs. LOI was calculated as the percentage mass loss during firing. $500^{\circ} \mathrm{C}, 650^{\circ} \mathrm{C}, 700^{\circ} \mathrm{C}$, or $800^{\circ} \mathrm{C}$ using 1,2 , or $3 \mathrm{hr}$ soak times. Finally, the ash was ground for one hour at 85 revolutions per minute (rpm) in a laboratory ball mill.

Particle-size distribution and internal surface area of the ground ARA were determined using 104

To measure the amorphous silica content of ARA, the ash impurities and soluble material content were measured (Nair, et al. 2006). The impurities content was measured by first boiling $0.5 \mathrm{~g}$ of ARA after the LOI test in $25 \mathrm{~mL}$ of $10 \%$ nitric acid. After boiling in acid the sample was filtered through a glass microfiber filter paper with $1.1 \mu \mathrm{m}$ openings and rinsed with deionized water. The sample was then dried at $90 \pm 10^{\circ} \mathrm{C}$ and weighed. To measure the ash soluble material content, $3 \mathrm{~g}$ of ARA was boiled in $200 \mathrm{~mL}$ of $10 \%$ sodium hydroxide solution (2.5 N NaOH) for 1075 minutes. After boiling, the sample was cooled to room temperature, filtered through a $1.1 \mu \mathrm{m}$ 108 glass microfiber filter paper, and washed with deionized water. The residue and filter paper was 109 then heated to $800{ }^{\circ} \mathrm{C}$ for 3 hrs. The ash weight change after boiling in the sodium hydroxide and 110 heating was recorded. The ARA amorphous silica content was then calculated using Eq. 2 :

$$
S i_{a m}=w_{s o l}-L O I-w_{i m} \quad \text { Eq. } 2
$$


111 where $S i_{a m}$ is the amorphous silica content of the ash (\%), $w_{s o l}$ is the ash weight loss after boiling

112 in sodium hydroxide and heating (\%), LOI is the ash loss on ignition (\%), and $w_{i m}$ is the weight

113 of impurities (\%).

114 The decrease in electrical conductivity of a calcium hydroxide solution mixed with SCMs

115 has been used by other researchers as a simple reactivity index for pozzolanic behavior of SCMs

116 (Sinthaworn and Nimityongskul 2009; Paya, et al. 2001) and was used in this study. One gram

117 of ARA was mixed with $100 \mathrm{~mL}$ of saturated calcium hydroxide solution at $23 \pm 2{ }^{\circ} \mathrm{C}$. The

118 solution's electrical conductivity was then measured for 7 days.

119 For the cement paste experiments, ARA was used at a $20 \%$ replacement level by mass of 120 cement when used. A water-cementitious materials ratio (w/cm) of 0.5 was used for all paste 121 samples. The paste samples were mixed using a procedure previously used (Riding, et al. 2010).

122 Distilled water was added to the cementitious material and mixed using a vertical laboratory 123 mixer at 500 rpm for 90 seconds, followed by a 120 second rest period, and finally mixed at 1242000 rpm for 120 seconds.

125 Isothermal calorimetry was used to study the reaction rate of ARA in a cementitious system. 126 An eight-channel isothermal calorimeter was used in this study at $23^{\circ} \mathrm{C}$. Paste samples of 127 approximately $30 \mathrm{~g}$ each were used. The calcium hydroxide $(\mathrm{CH})$ content of cement paste 128 samples was measured by thermogravimetric analysis to study the pozzolanic consumption of $129 \mathrm{CH}$ by ARA. Samples were wet cured starting at 24 hrs after casting at $23{ }^{\circ} \mathrm{C}$. Cement paste 130 hydration was stopped at 7, 28, and 90 days after mixing by means of solvent exchange with 131 isopropanol. 3-5mm thick samples were cut and placed in isopropanol for 7 days. After 7 days 132 in isopropanol, the samples were dried in a vacuum for at least 3 days. For thermogrametric 133 analysis, samples were heated at $20^{\circ} \mathrm{C} / \mathrm{min}$ up to $900^{\circ} \mathrm{C}$ in a nitrogen environment. 
Mortar cube compressive strength was measured according to ASTM C 109 (2008) with a 139 cubes. sand to cementitious material ratio of 2.75. A w/cm of 0.55 was used for all mortar samples because of the decreased workability of systems with ARA. ARA was used at a 20\% replacement level by mass of cement when used. Mortar cube compressive strength was tested at 7 and 28 days with the results reported as the average of the compressive strength of three mortar

\section{Results and discussion:}

\section{Pretreatments and alkali leaching}

Pretreatments were very effective in altering the chemical and physical structure of the straw and removing K, Ca, and Mg. Figure 1 shows the leachate K concentrations for different pretreatments used for WS. The sodium concentrations were found to be much lower than K, and varied only slightly by pretreatment method. Figure 2 shows the calcium $(\mathrm{Ca})$ and magnesium (Mg) leachate concentration for WS. $\mathrm{HCl}$ and higher temperatures increased the leaching rates of $\mathrm{K}$, Ca, and Mg. A much larger difference between $\mathrm{HCl}$ and $\mathrm{DW}$ pretreatments was seen however with $\mathrm{Ca}$ and $\mathrm{Mg}$ removal from WS than K and Na. Similar trends were observed for RS. The temperature sensitivity of K removal during pretreatments was quantified by calculating the dissolution activation energy. First, the leachate $\mathrm{K}$ concentration with time for a given pretreatment temperature was fit to Eq. 3 (ASTM, 2010):

$$
C(t)=C_{u l t} \frac{K \cdot(t)}{1+K \cdot(t)} \quad \text { Eq. } 3
$$

where $C(t)$ is the potassium concentration as a function of soaking duration (ppm), $t$ is the time passed after starting the pretreatment (days), $C_{\text {ult }}$ is the ultimate potassium concentration assumed 
156 to be equal to the concentration measured at $24 \mathrm{hr}$ of treatment (ppm), and $K$ is the rate constant 157 of potassium dissolution. The Arrhenius plot was made by plotting the natural log of the rate 158 constant $\mathrm{K}$ against the reciprocal of the pretreatment temperature in Kelvins. Figure 3 shows the 159 Arrhenius plot for the rate constants calculated for the leachate K concentration for wheat straw. 160 The activation energy was calculated as the slope of the fit line on the Arrhenius plot multiplied 161 by the universal gas constant $\mathrm{R}(8.314 \mathrm{~J} / \mathrm{mol} / \mathrm{K})$. The activation energy for leaching $\mathrm{K}$ with 0.1

$162 \mathrm{~N} \mathrm{HCl}$ was found to be $32.2 \mathrm{KJ} / \mathrm{mol}$, versus $13.3 \mathrm{KJ} / \mathrm{mol}$ with DW pretreatments. This shows 163 that the higher the acid concentration the more effectively heat can be used to remove $\mathrm{K}$ from the 164 AR with high acid concentrations.

165 Surface area, LOI and amorphous silica content of ARA

166 Pretreatments were effective in reducing the carbon content in the ARA, increasing the 167 internal surface area, and increasing the percentage of amorphous silica in the ash. Figure 4 168 shows the amorphous silica content of ARA. For a given burning temperature, pretreatments 169 increased the amorphous silica content. Pretreated ARA burned at $500^{\circ} \mathrm{C}$ for 2 hrs had a similar 170 amorphous silica content as the one burned at $650^{\circ} \mathrm{C}$ for $1 \mathrm{hr}$. The unpretreated WSA had $21 \%$ 171 crystalline silica and unpretreated RSA had $19 \%$ crystalline silica when burned at $650^{\circ} \mathrm{C}$ for 1 172 hour as calculated from the ash total silica content shown in Table 2 and the ash amorphous 173 silica content shown in Figure 4 . The ash pretreated with $0.1 \mathrm{~N} \mathrm{HCl}$ at $80^{\circ} \mathrm{C}$ showed little if any 174 crystalline silica while the WSA pretreated with DW at $80^{\circ} \mathrm{C}$ had $8 \%$ crystalline silica. The 175 increase in amorphous silica content of the pretreated ARA correlated with the removal of Ca, $176 \mathrm{Mg}$, and $\mathrm{K}$ out of the biomass by pretreatments. Figure 5 shows the amorphous silica content of 177 ARA versus the $\mathrm{CaO}, \mathrm{MgO}$, and $\mathrm{K}_{2} \mathrm{O}$ content. The amorphous silica content of the ARA 178 corresponded with a decrease in the $\mathrm{CaO}, \mathrm{MgO}$, and $\mathrm{K}_{2} \mathrm{O}$ content, with the $\mathrm{MgO}$ showing a 
179 slightly better correlation. Figure 6 shows the LOI measured for WSA and RSA. The ARA LOI 180 decreases as the burning temperature increases regardless of the pretreatment type. At a given 181 burning temperature, pretreated ARA had a lower LOI than that of the unpretreated control ash. 182 Figure 7 shows the metal impurity (Ca, Mg, and K) content of the ash for the WSA and RSA was 183 also correlated to the ARA LOI. The RSA had a lower LOI than the corresponding WSA, 184 possibly because of the lower alkali content of the RSA before pretreatment than the WSA. Even 185 though distilled water pretreatments were not as effective as the more acidic pretreatments, when 186 burned at $650^{\circ} \mathrm{C}$ for 1 hr the WSA pretreated with DW23/24 still had 52\% lower LOI and $15 \%$ 187 higher amorphous silica than that of unpretreated WSA. RSA pretreated with DW23/24 had 55\% 188 lower LOI and 17\% higher amorphous silica than that of unpretreated RSA.

189 Another important impact of the pretreatments is the decrease in temperature sensitivity of 190 the biomass. Sensitivity reduction is vital for low cost ARA production in using simple kilns or 191 large scale applications where it may be more difficult to control the temperature. The 192 pretreatments were very effective in reducing the sensitivity to burning temperatures. The $193 \mathrm{HCl}$ Ho/24 WSA burned at $800{ }^{\circ} \mathrm{C}$ had a higher amorphous $\mathrm{SiO}_{2}$ content than that of the control 194 burned at $500^{\circ} \mathrm{C}$ as shown in Figure 4.

195 LOI and amorphous silica content of ARA was shown to be affected by the duration of 196 burning. Table 4 shows the LOI and amorphous silica content for WSA pretreated with 0.1N $197 \mathrm{HCl}$ at $80^{\circ} \mathrm{C}$ for 24 hours and then burned at different temperatures and holding durations. There 198 appears to be an optimum burning time for each temperature which appeared to coincide with the 199 removal of most of the carbon. At $500^{\circ} \mathrm{C}$, the optimum burning time was found to be between 200 one and two hours whereas at $600^{\circ} \mathrm{C}$ it was found to be less than or equal to one hour. Burning 
201 periods longer than the optimum time did not appear to improve amorphous silica content or 202 LOI.

203 The pretreatment changed the color of the ash, mainly because of the decrease in carbon 204 content. Figure 8A shows WSA pretreated with $0.1 \mathrm{~N} \mathrm{HCl}$ at $80^{\circ} \mathrm{C}$ for 24 hrs, while Figure $8 \mathrm{~B}$ 205 shows control WSA samples ashed at four different temperatures. The WSA-HCL80/24 ash was 206 much lighter in color than that of control WSA ashes regardless of the burning condition. Even 207 though it had a low LOI, the WSA pretreated with $\mathrm{HCl}$ at $80^{\circ} \mathrm{C}$ for $24 \mathrm{hrs}$ and burned at $800^{\circ} \mathrm{C}$ 208 for one hr had a slightly darker color than the pretreated ashes made at lower temperatures 209 (Figure 8A). Although the color of the ash is largely related to carbon content of the ash, 210 impurities such as alkali metals can change the ash color. At higher temperatures these metals 211 react with silicon $(\mathrm{Si})$ to produce crystalline phases that may combined with carbon or contain 212 iron giving the ash a darker color (Muthadhi and Kothandaraman 2010; Genieva, et al. 2011). It 213 was also observed that washing the biomass after pretreatments is very important in removing 214 alkalis from surface of biomass and reducing LOI of the resulted ash. This could be because 215 when the straw was not washed after the pretreatment, potassium and other impurities in solution 216 would precipitate on to the surface of the straw during drying. These precipitates could trap 217 carbon during ashing, leading to higher ash LOI. Even though pretreatments remove metal 218 impurities out of the biomass cell wall, it is beneficial to wash the biomass after pretreatment to 219 limit the impurities that would precipitate on the biomass surface. For a given burning condition, 220 pretreated but unwashed biomass resulted in ARA with darker color and higher LOI compared to 221 the ash obtained from pretreated and washed biomass. This could be attributed alkalis on the 222 surface melting at lower temperature and trapping carbon. 
Table 3 presents the ARA surface area determined by BET nitrogen adsorption while Figure 2249 shows the particle-size distribution for some selected ARAs. For a given pretreatment, ashes 225 burned at $500^{\circ} \mathrm{C}$ for 2 hrs had higher surface area than those burned at higher temperatures. This 226 is probably because at higher temperatures melting of some material may occur eliminating 227 pores inside of the ash. The particle-size distribution was not significantly affected by 228 pretreatments. Although the surface area of unpretreated RSA and WSA were similar, pretreated 229 RSA had a larger surface area than that of pretreated WSA.

\section{Conductivity measurements}

Figure 10 shows the normalized conductivity (the measured conductivity divided by the 232 initial conductivity of the solution) data for WSA pretreated with $0.1 \mathrm{~N} \mathrm{HCl}$ at $23^{\circ} \mathrm{C}, 50^{\circ} \mathrm{C}$, and $23380^{\circ} \mathrm{C}$ and burned at $500^{\circ} \mathrm{C}$ for 2 hours and $650^{\circ} \mathrm{C}$ for 1 hour. The normalized conductivity for 234 unpretreated WSA and WSA pretreated with DW and $0.1 \mathrm{~N} \mathrm{HCl}$ is given in Figure 11. The 235 pretreatment temperature did not significantly affect the measured conductivity change. WSA 236 burned at $500^{\circ} \mathrm{C}$ for 2 hrs shows a more rapid drop in conductivity than WSA burned at $650^{\circ} \mathrm{C}$ 237 for 1 hour indicating a higher reactivity consistent with the higher surface ash measured in the 238 samples burned at $500^{\circ} \mathrm{C}$. Very little difference was seen between different pretreatments in the 239 conductivity experiments. Similar behavior was seen for RSA conductivity experiments. The 240 initial increase in the electrical conductivity from the control sample is likely the result of 241 dissolution of metal impurities such as $\mathrm{Na}, \mathrm{K}, \mathrm{Ca}$, and $\mathrm{Mg}$ in the solution (Sinthaworn, et al. 242 2011).

243 Isothermal Heat of Hydration

Figure 12 compares the heat of hydration for WSA burned at $650^{\circ} \mathrm{C}$ for 1 hour with and 245 without thermochemical pretreatments. Large differences in hydration behavior were seen 
246 between the pretreated and control WSA. Figure 13 shows the total heat of hydration of cement 247 paste samples containing WSA. The pretreated ashes show similar total heat of hydration during 248 the first 120 hours, indicating a similar degree of cement hydration at 120 hours. Figure 14 249 shows the heat flow rate for paste samples containing RSA. The hydration rate of pretreated 250 ARA was accelerated compared to the control samples, whereas the samples with ARA that were 251 not pretreated were retarded as seen in Figure 12 and Figure 14. The hydration acceleration is 252 most likely caused by increased nucleation because of the very high ARA surface area (Bullard, 253 et al. 2011; Scrivener and Nonat 2011). Also, the samples containing pretreated ARA (WSA and 254 RSA) showed much more similar behavior to each other during the first 120 hours after mixing 255 than the non-pretreated ARA.

256 Pozzolanic Reactivity

The decrease in $\mathrm{CH}$ content of cement paste samples containing ARA is a measure of the 258 ARA pozzolanic reaction. The $\mathrm{CH}$ content for cement paste samples with and without ARA was 259 measured using TGA at 7, 28, and 90 days of hydration as shown in Figure 15 and 16 for WSA 260 and RSA, respectively. For a given pretreatment type and age, samples containing ARA (WSA 261 or RSA) burned at $500^{\circ} \mathrm{C}$ for $2 \mathrm{hr}$ had a lower $\mathrm{CH}$ content than those burned at higher 262 temperatures. This can be attributed to the higher surface area of ARA burned at $500^{\circ} \mathrm{C}$ for $2 \mathrm{hr}$. 263 At a given burning condition, samples containing ARA pretreated with $0.1 \mathrm{~N} \mathrm{HCl}$ at $80^{\circ} \mathrm{C}$ for 24 264 hrs had a lower $\mathrm{CH}$ content than any other pretreatment type. At a given age, samples containing 265 WSA at burned at $500^{\circ} \mathrm{C}$ showed lower $\mathrm{CH}$ content than those containing RSA burned at $500^{\circ} \mathrm{C}$.

Figure 17 shows the compressive strength development for mortar with and without $20 \%$ 267 cement replaced by ARA. The WSA and RSA pretreated with $\mathrm{HCl}$ at $80^{\circ} \mathrm{C}$ for 24 hours showed 268 the highest compressive strength development, with a $25 \%$ increase in strength over the ordinary 
269 portland cement (OPC) mixture at 28 days of age. The increased strength seen with pretreated 270 ashes confirms the increased pozzolanic reaction seen with the reduction of $\mathrm{CH}$ content with 271 time in samples containing the pretreated ARA.

272 A comparison of the ARA material characteristic improvement from the pretreatments 273 (amorphous silica and surface area) and $\mathrm{CH}$ content at 90 days is shown in Figure 18. The 274 increase in amorphous silica content of ARA and surface area correlated with a decrease in the $275 \mathrm{CH}$ content of paste samples containing ARA and increases compressive strength of mortar 276 samples containing ARA. The isothermal calorimetry results did not show a reduced hydration 277 development with the use of ARA indicating that the decrease in $\mathrm{CH}$ content seen with the ARA 278 is likely from the pozzolanic reaction and not a lower cement degree of hydration. Additionally 279 the OPC mixture showed an increase in $\mathrm{CH}$ content while the mixtures with ARA showed a 280 decrease in $\mathrm{CH}$ between 7 and 28 days.

281 Conclusions:

282

The material physical and pozzolanic properties of wheat straw ash (WSA) and rice straw ash

283 (RSA) were studied. From this study, the following conclusions can be made:

284 1- Pretreatments are effective in partial removal of $\mathrm{Ca}, \mathrm{K}$, and $\mathrm{Mg}$ out of the biomass. The 285 286 activation energy for $\mathrm{K}$ leaching was higher for dilute acid pretreatment than distilled water pretreatment. This shows that heating samples during pretreatment even more effective for the more acidic pretreatments.

2- Pretreatments increased the amorphous silica content and surface area and decreased the LOI of ARA at a given burning temperature. It was shown that amorphous silica content inversely correlated with the $\mathrm{Ca}, \mathrm{K}$, and $\mathrm{Mg}$ content of the ash while LOI of ARA is directly correlated with the $\mathrm{Ca}, \mathrm{K}$, and Mg content of the ash. Alkalis seemed to encase or 
combine with carbon during burning. Pretreatments reduced the sensitivity of the ash to

\section{Acknowledgements:}

313 Financial support for this project was provided by the National Science Foundation (CMMI314 103093). The authors thank Dr. Donn Beighley for providing the rice straw. The help of Dr. 
Kenneth J. Klabunde for providing access to the BET Nitrogen equipment is appreciated. The help of Monarch Cement Company in chemical analysis of samples is greatly acknowledged. Valuable advice from Dr. Maria Juenger throughout this paper is greatly appreciated. Antoine Borden's assistance with the pretreatment experiments is gratefully acknowledged.

\section{References}

Agarwal, S.K. (2006) "Pozzolanic activity of various siliceous materials." Cement and Concrete Research, 36(9), 1735-1739.

Al-Akhras, N.M., and B.A. Abu-Alfoul. (2002) "Effect of wheatstrawash on mechanical properties of autoclaved mortar." Cement and Concrete Research, 32(6), 859-863.

ASTM. (2010) "Standard Practice for Estimating Concrete Strength by the Maturity Method." C1074, West Conshohocken, PA.

ASTM. (2009) "Standard Specification for Portland Cement." C150, West Conshohocken, PA. ASTM. (2006) "Standard Specification for Standard Sand." C778, West Conshohocken, PA. ASTM. (2008) "Standard Test Method for Compressive Strength of Hydraulic Cement Mortars." C109, West Conshohocken, PA.

Biricik, H., F. Akoz, I. Berkaty, and A.N. Tulgar. (1999) "Study of pozzolanic properties of wheat straw ash." Cement and Concrete Research, 29(5), 637-643.

Bullard, J.W., H.M. Jennings, R.A. Livingston, A. Nonat, G.W. Scherer, G.W., J.|S. Schweitzer, K.L. Scrivener, J.J. Thomas. (2011) "Mechanisms of cement hydration." Cement and Concrete Research, 41(12), 1208-1223.

Chandrasekhar, S., P.N. Pramada, and J. Majeed. (2006) "Effect of calcination temperature and heating rate on the optical properties and reactivity of rice husk ash." Journal of Materials Science, 41(23), 7926-7933.

Cordeiro, G.C., R.D. Toledo-Filho, and E.M. Rego-Fairbairn. (2006) "Use of ultrafine rice husk ash with high-carbon content as pozzolan in high performance concrete." Materials and Structures, 42(7), 983-992.

El-Damatty, A.A., and I. Hussain. (2007) "An economical solution fo the environmental problem resulting from disposal of rice straw." ERTEP. Ghana, Africa: Springer, 15-24. 
344 Feng, Q., H. Yamamichi, M. Shoya, and S. Sugita. (2004) "Study on the pozzolanic properties of 345 rice husk ash by hydrochloric acid pretreatment." Cement and Concrete Research, 34(3), 521346526.

347 Francisco, T., J. Paul, and R. AustriacoLilia. (2008) "Compressive strenght of concrete blended 348 with calcined rice straw ash." The 3rd ACF International Conference. Ho Chi Minh, Vietnam, $349 \quad 592-597$.

350 Genieva, S.D., S.C. Turmanova, and L.T. Vlaev. (2011) "Utilization of rice husks and the 351 products of its thermal degradation as fillers in polymer composites." Edited by S. Kalia, B.S. 352 Kaith and I. Kau. Springer, 345-375.

353 Jenkins, B.M., J.D. Mannapperuma, and R.R. Bakker. (2003) "Biomass leachate treatment by 354 reverse osmosis." Fuel Processing Technology, 81(3), 223-246.

355 Kristensen, J.B., L.G. Thygesen, C. Felby, H. Jorgensen, and T. Elder. (2008) "Cell-wall 356 structural changes in wheat straw pretreated for bioethonal production." Biotechnology for 357 Biofuels, 1(5).

358 M osier, N., Wyman, C., Dale, B., Elander, R., Lee, Y.Y., Holtzapple, M., and Ladisch, M. 359 (2005) "Features of promising technologies for pretreatment of lignocellulosic biomass." 360 Bioresources Technology, 96(6), 673-686.

361 Muthadhi, A., and S. Kothandaraman. (2010) "Optimum production condiction for reactive rice 362 husk ash." Materials and Structures, 43(9), 1303-1315.

363 Nair, G., S. Jagadish, and A. Fraaij. (2006) "Reactive pozzolanas from rice husk ash: An 364 alternative to cement for rural housing." Cement and Concrete Research, 36(6), 1062-1071.

365 Paya, J., M.V. Borrachero, J. Monzo, and E, Peris-Mora. (2001) "Enhanced conductivity 366 measurement techniques for evaluation of fly ash pozzolanic activity." Cement and Concrete 367 Research, 31(1), 41-49.

368 Riding, K., D.A. Silva, and K. Scrivener. (2010) "Early age strength of blend cement systems by $369 \mathrm{CaCl} 2$ and diethanol-isopropanolmine." Cement and Concrete Research, 40(6), 935-946.

370 Saha, B.C., L.B. Iten, M.A. Cotta, and Y.V. Wu. (2005) "Dilute acid pretreatment, enzymatic 371 saccharification and fermentation of wheat straw to ethanol." Process Biochemistry, 40(12), 372 3693-3700.

373 Salas, A., S. Delvastoa, R.M. Gutierreza, and D. Lange. (2009) "Comparison of two processes 374 for treating rice husk ash for use in high performance concrete." Cement and Concrete research, 375 39(9), 773-778. 
376 Sales, A., and L. Sofia. (2010) "Use of Brazilian sugarcae bagasse ash in concrete as sand 377 replacement." Waste Management, 30(6), 1114-1122.

378 Scrivener, K.L., and A. Nonat. (2011) "Hydration of cementitious materials, present and future." 379 Cement and Concrete Research, 41(7), 651-665.

380 Sinthaworn, S., and P. Nimityongskul. (2011) "Effects of temperature and alkaline solution on 381 electrical conductivity measurements of pozzolanic activity." Cement and Concrete Research, 382 33(5), 622-627.

383 Sinthaworn, S., and P. Nimityongskul. (2009)"Quick monitoring of pozzolanic reactivity of 384 waste ashes." Waste Management, 29(9), 1526-1531.

385 Tuan, N.V., G. Ye, K.V. Breugel, and O. Copuroglu. (2011) "Hydration and microstructure of 386 ultra high performance concrete incorporating rice husk ash." Cement and Concrete Research, 387 41(11), 1105-1111.

388 Wansom, S., S. Janjaturaphan, and S. Sinthupinyo. (2010) "Characterizing pozzolanic activity of 389 rice husk ash by impendence spectroscopy." Cement and Concrete Research, 40(12), 1714-1722.

390 Wansom, S., S. Janjaturaphan, and S. Sinthupinyo. (2009) "Pozzolanic Activity of Rice Husk 391 Ash: Comparison of Various Electrical Methods." Journal of Metals, Materials and Minerals, 392 19(2), 1-7.

393 Zheng, Y., Z. Pan, and R. Zhang. (2009) "Overview of biomass pretreatment for cellulosic 394 ethanol production." International Journal of Agricultural and Biological Engineering, 2(3), 5139568. 


\section{List of tables}

Table 1: ASTM C 150 Type I/II ordinary portland cement (OPC) Composition. 19

Table 2: Oxide composition of selected ARA

Table 3: BET data for WSA and RSA under different burning conditions

\section{List of figures}

404 Figure 1: Potassium (K) concentration for wheat straw 23

412 Figure 9: Particle size distribution of OPC and ARAs 26

413 Figure 10: Electrical conductivity change of $\mathrm{HCl}$ pretreated wheat straw ash 26

414 Figure 11: Electrical conductivity change wheat straw ash with different pretreatments 27

415 Figure 12: Heat flow rate of paste samples containing different wheat straw ash 27

416 Figure 13: Total heat of hydration of paste samples containing different wheat straw ash......... 28

417 Figure 14: Heat evolution rate of paste samples with and without rice straw ash. 28

418 Figure 15: $\mathrm{CH}$ content of cement paste containing wheat straw ash 28

419 Figure 16: CH content of cement paste containing rice straw ash. 29 
420 Figure 17: Mortar cube compressive strength data..

421 Figure 18: Relation between material characteristics and performance a) amorphous silica

422 content vs 28 days mortar cub strength, b) amorphous silica content vs CH content of paste after

42390 days c) Surface area of ash vs $\mathrm{CH}$ content of paste after 90 days .................................... 30

424 
426

427

428

429

Table 1: ASTM C 150 Type I/II ordinary portland cement (OPC) Composition

\begin{tabular}{|c|c|}
\hline \multicolumn{2}{|c|}{$\begin{array}{c}\text { Chemical } \\
\text { Composition (wt\%) }\end{array}$} \\
\hline $\mathrm{SiO}_{2}$ & 21.85 \\
\hline $\mathrm{Fe}_{2} \mathrm{O}_{3}$ & 3.4 \\
\hline $\mathrm{Al}_{2} \mathrm{O}_{3}$ & 4.35 \\
\hline $\mathrm{CaO}$ & 64.19 \\
\hline $\mathrm{MgO}$ & 1.79 \\
\hline $\mathrm{K}_{2} \mathrm{O}$ & 0.52 \\
\hline $\mathrm{Na}_{2} \mathrm{O}$ & 0.17 \\
\hline $\mathrm{SO}_{3}$ & 2.77 \\
\hline LOI & 0.89 \\
\hline $\begin{array}{r}\text { Blaine } \\
\text { area }=3\end{array}$ & $\begin{array}{l}\text { ace } \\
n^{2} / \mathrm{kg}\end{array}$ \\
\hline
\end{tabular}

430

431 
433 Table 2: Oxide composition of selected ARA

\begin{tabular}{|l|c|c|c|c|c|c|c|}
\hline \multicolumn{1}{|c|}{ Ash Type } & $\mathrm{SiO}_{2}$ & $\mathrm{Al}_{2} \mathrm{O}_{3}$ & $\mathrm{Fe}_{2} \mathrm{O}_{3}$ & $\mathrm{CaO}$ & $\mathrm{MgO}$ & $\mathrm{K}_{2} \mathrm{O}$ & $\mathrm{Na}_{2} \mathrm{O}$ \\
\hline WSA-Cont-650/1 & 66.3 & 0.26 & 1.12 & 14.3 & 3.05 & 14.7 & 0.15 \\
\hline WSA-DW80-650/1 & 78.8 & 0.12 & 1.05 & 13.2 & 2.61 & 4.4 & 0.12 \\
\hline WSA-HCl80-650/1 & 86.5 & 0.28 & 1.13 & 9.73 & 0.78 & 1.54 & 0.1 \\
\hline WSA-HCl80-500/2 & 87.9 & 0.05 & 1.07 & 9.63 & 0.63 & 0.7 & 0.08 \\
\hline RSA-Cont-650/1 & 79.1 & 0.34 & 0.82 & 11.6 & 2.54 & 5.18 & 0.5 \\
\hline RSA-DW80-650/1 & 85.4 & 0.45 & 0.92 & 10.69 & 1.36 & 0.96 & 0.26 \\
\hline RSA-HCl80-650/1 & 88.2 & 0.47 & 0.74 & 9.48 & 0.56 & 0.31 & 0.17 \\
\hline RSA-HCl80-500/2 & 85.7 & 1.4 & 1.02 & 10.73 & 0.6 & 0.34 & 0.23 \\
\hline
\end{tabular}

434

435 
Table 3: BET data for WSA and RSA under different burning conditions

\begin{tabular}{|l|c|}
\hline \multicolumn{1}{|c|}{ Ash type } & $\begin{array}{c}\text { BET surface } \\
\text { area }\left(\mathrm{m}^{2} / \mathrm{g}\right)\end{array}$ \\
\hline WSA-Cont-500/2 & 27.6 \\
\hline WSA-Cont-650/1 & 8.3 \\
\hline WSA-HCl80/24-500/2 & 168 \\
\hline WSA-HCl80/24-650/1 & 65 \\
\hline WSA-HCl80/24-700/1 & 39.7 \\
\hline RSA-Cont-500/2 & 16.9 \\
\hline RSA-Cont-650/1 & 9.6 \\
\hline RSA-HCl80/24-500/2 & 200 \\
\hline RSA-HCl80/24-650/1 & 134.5 \\
\hline RSA-DW80/24-650/1 & 58.94 \\
\hline
\end{tabular}

438

439 
Table 4: Effect of holding time on LOI and amorphous silica content

\begin{tabular}{|c|r|r|}
\hline WSA type & $\begin{array}{c}\text { Amorphous } \\
\text { Silica (\%) }\end{array}$ & LOI (\%) \\
\hline $\mathrm{HCl} 80 / 24-500 / 1$ & 72.70 & 17.58 \\
\hline $\mathrm{HCl} 80 / 24-500 / 2$ & 88.65 & 2.76 \\
\hline $\mathrm{HCl} 80 / 24-500 / 3$ & 88.7 & 2.62 \\
\hline $\mathrm{HCl} 80 / 24-650 / 1$ & 89.14 & 1.18 \\
\hline $\mathrm{HCl} 80 / 24-650 / 2$ & 88.99 & 1.1 \\
\hline
\end{tabular}

442

443 


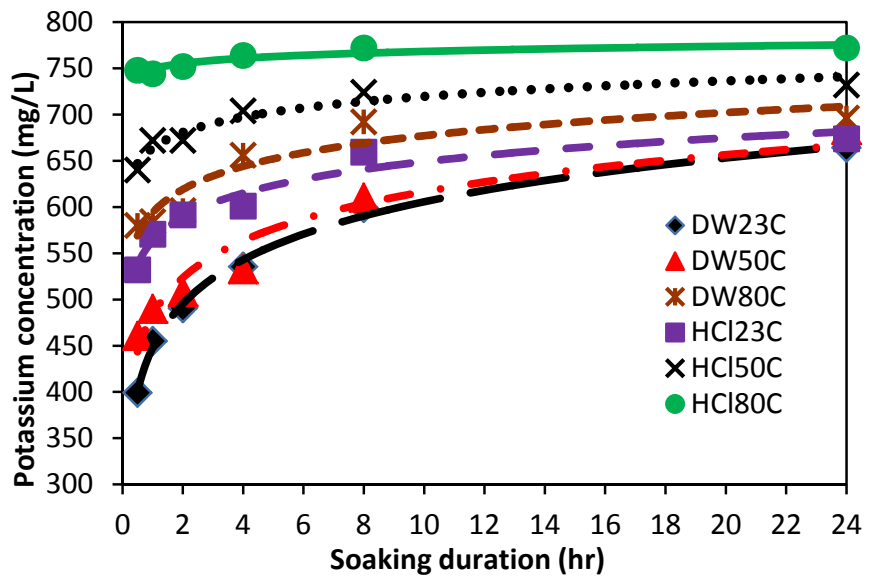

Figure 1: Potassium (K) concentration for wheat straw
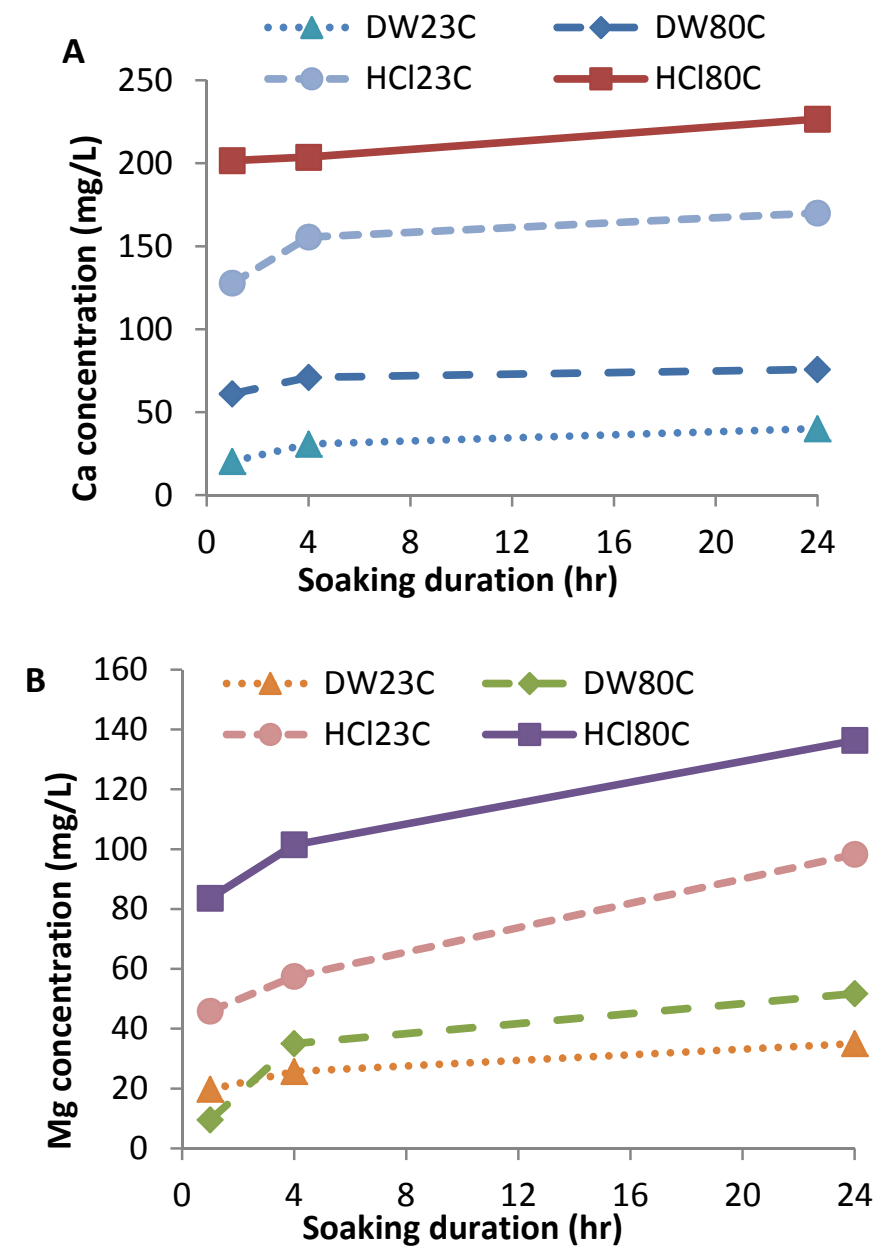

Figure 2: Ca (a) and (b) Mg concentration for wheat straw 


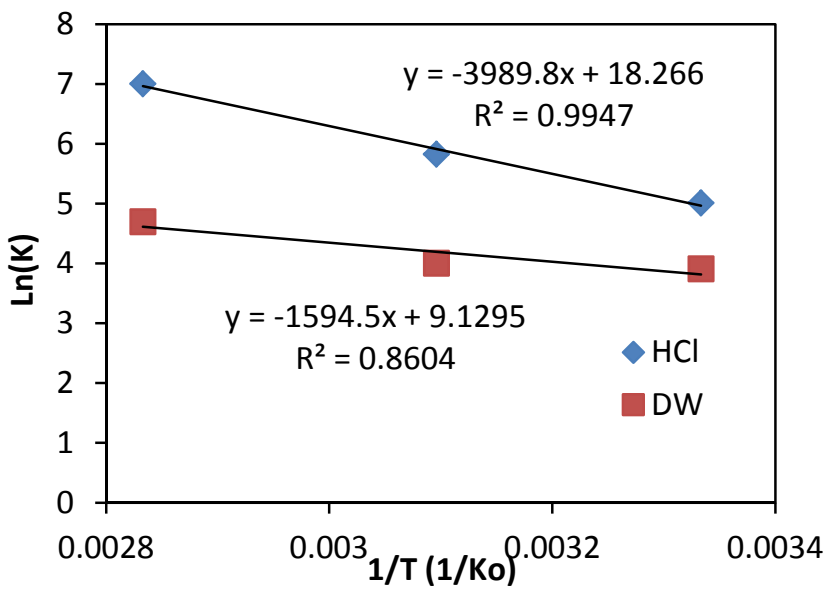

Figure 3: Arrhenius Plot for wheat straw

452

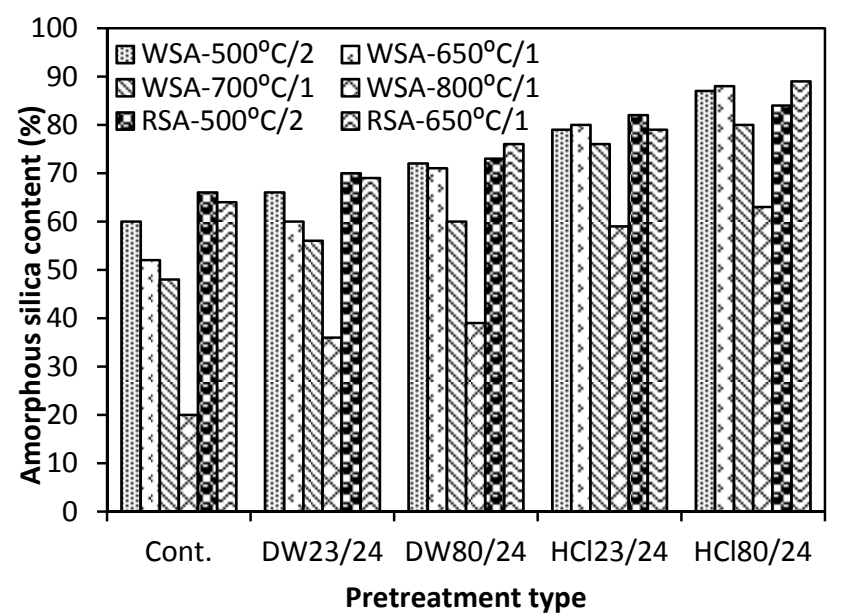



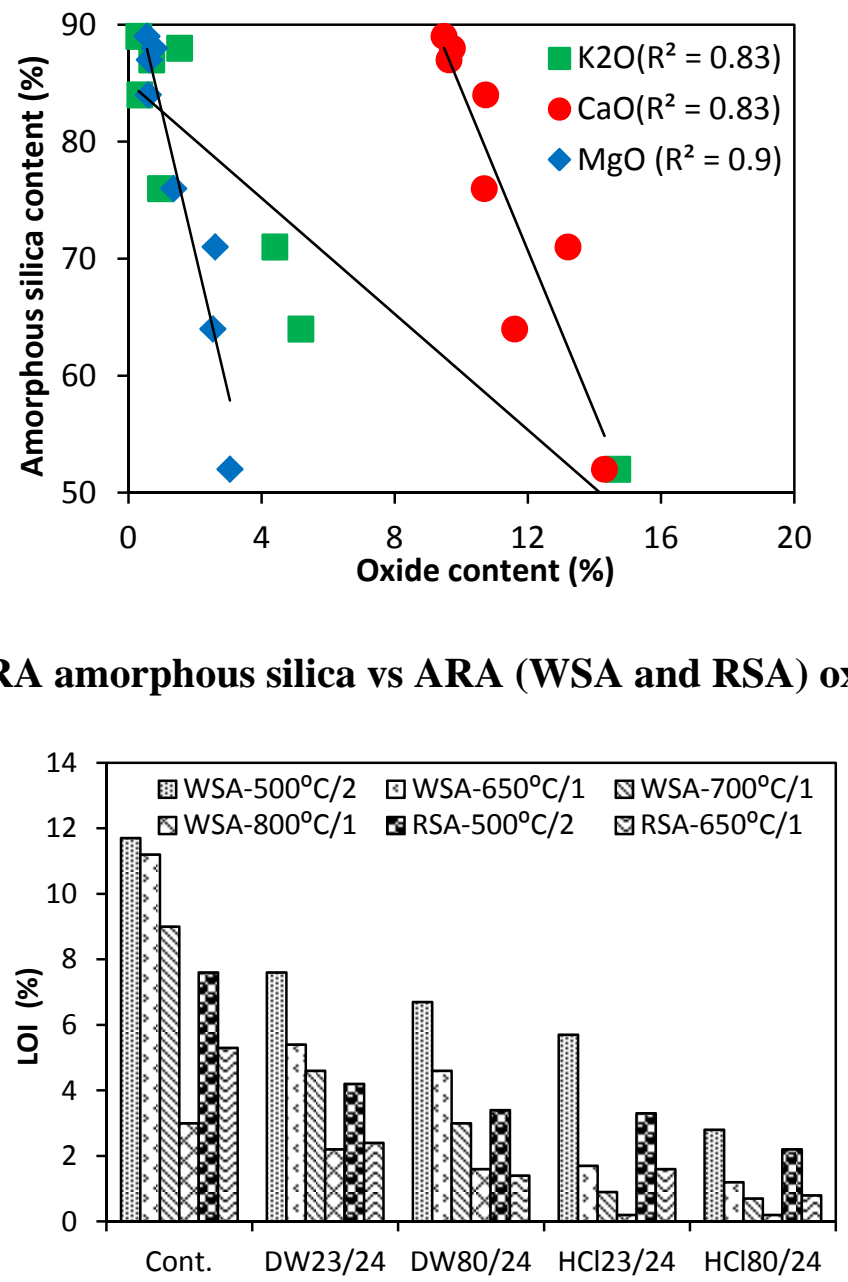
Pretreatment type

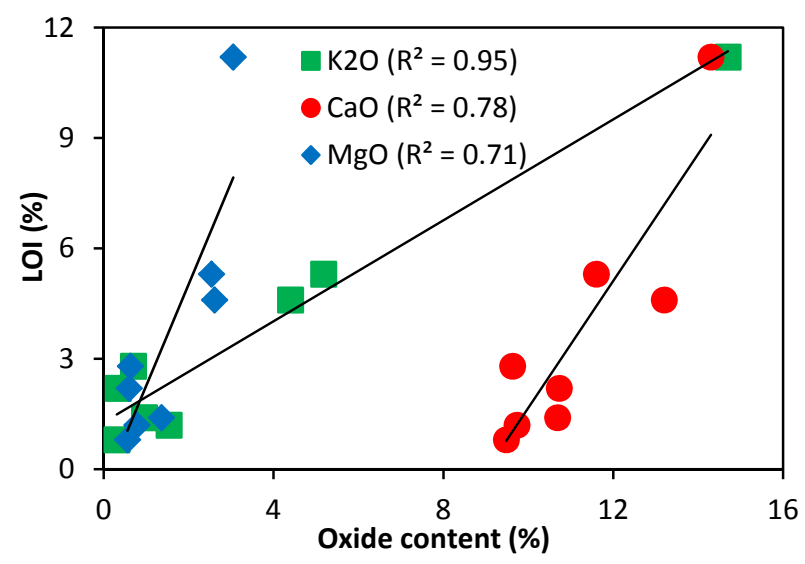

Figure 7: ARA LOI V vs ash $\mathrm{K}_{2} \mathrm{O}, \mathrm{CaO}$ and $\mathrm{MgO}$ content 


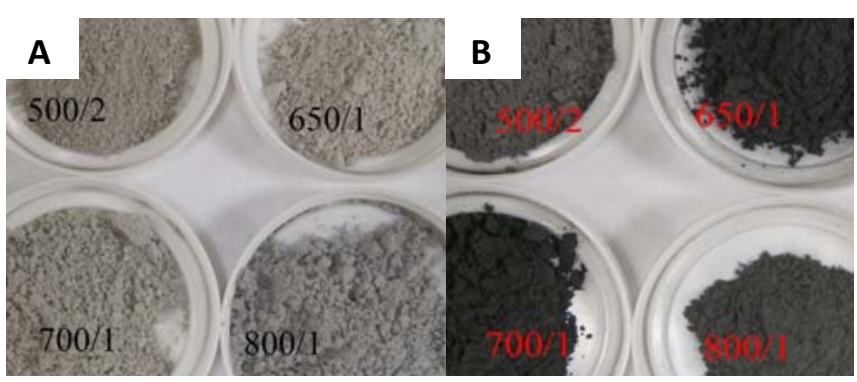

Figure 8: Color of wheat straw ash, a) $\mathrm{HCl80/24}$ pretreated and b) unpretreated
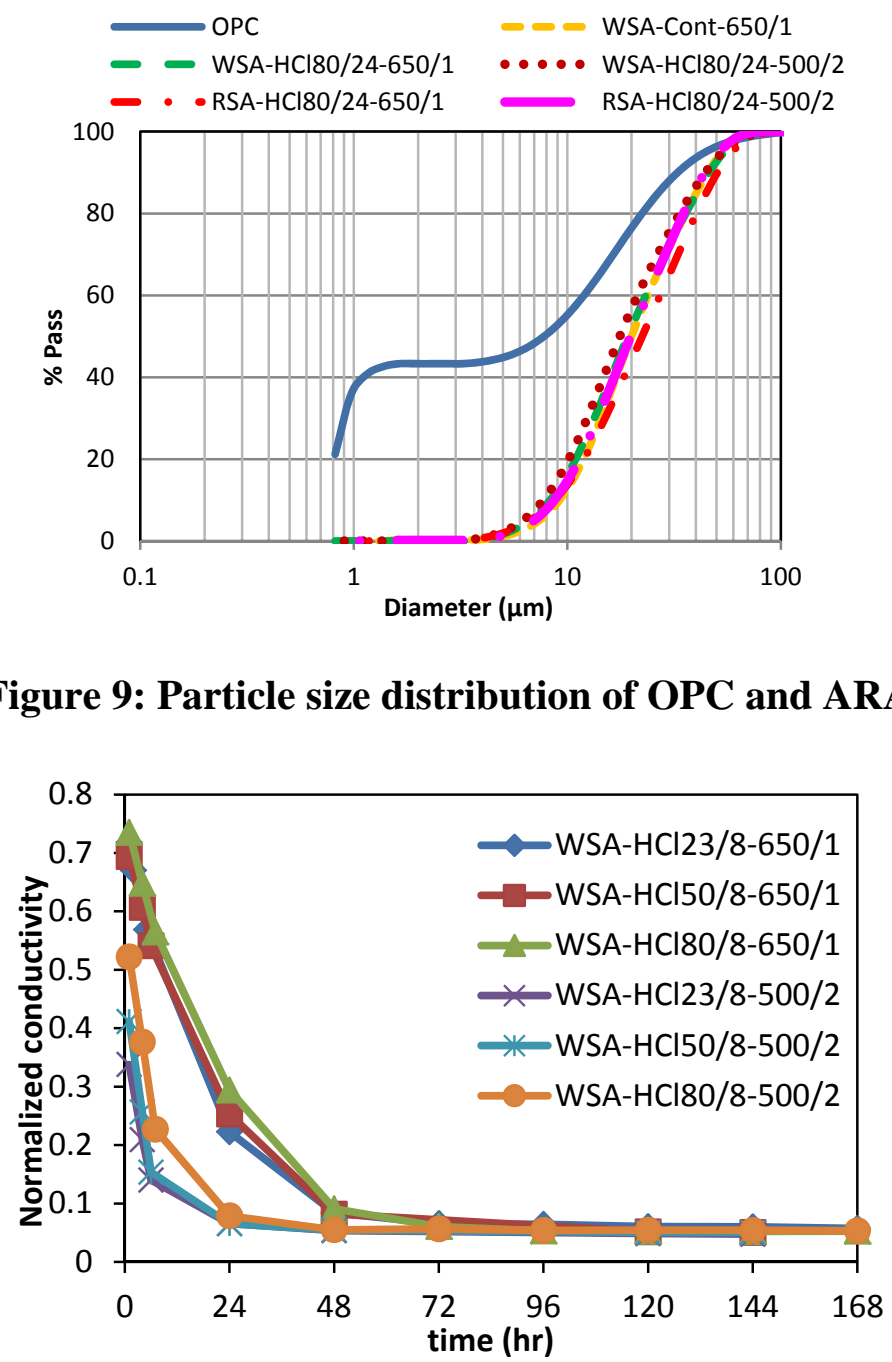

Figure 10: Electrical conductivity change of $\mathrm{HCl}$ pretreated wheat straw ash 


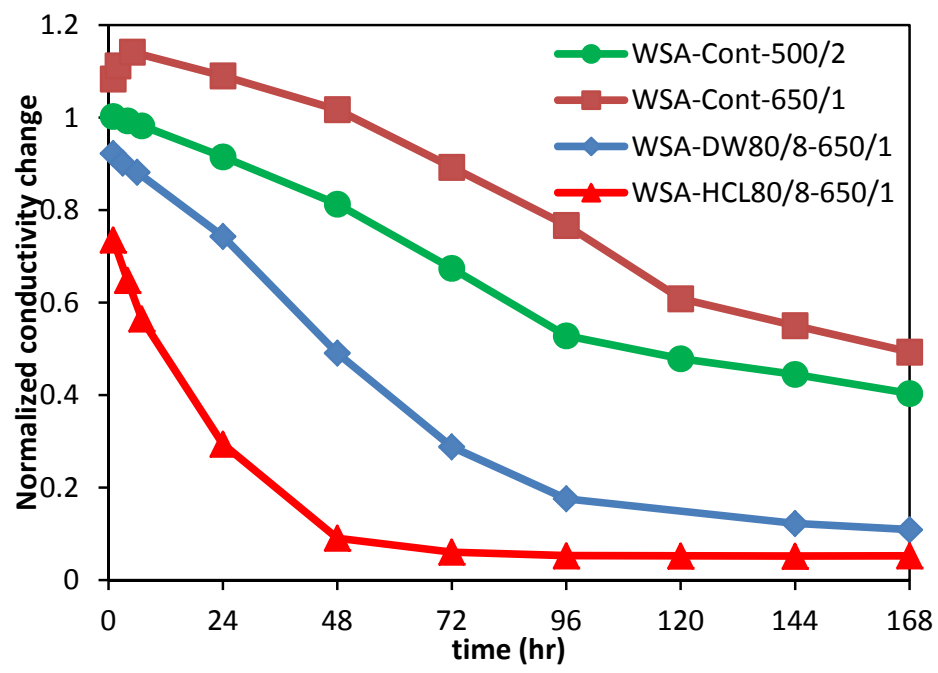

468 Figure 11: Electrical conductivity change wheat straw ash with different pretreatments

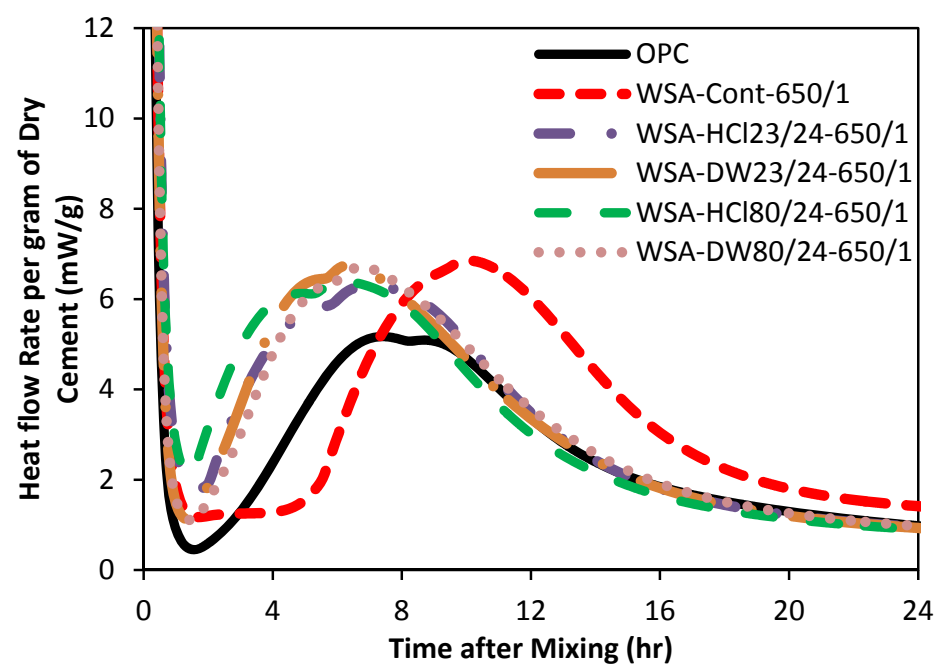

Figure 12: Heat flow rate of paste samples containing different wheat straw ash 


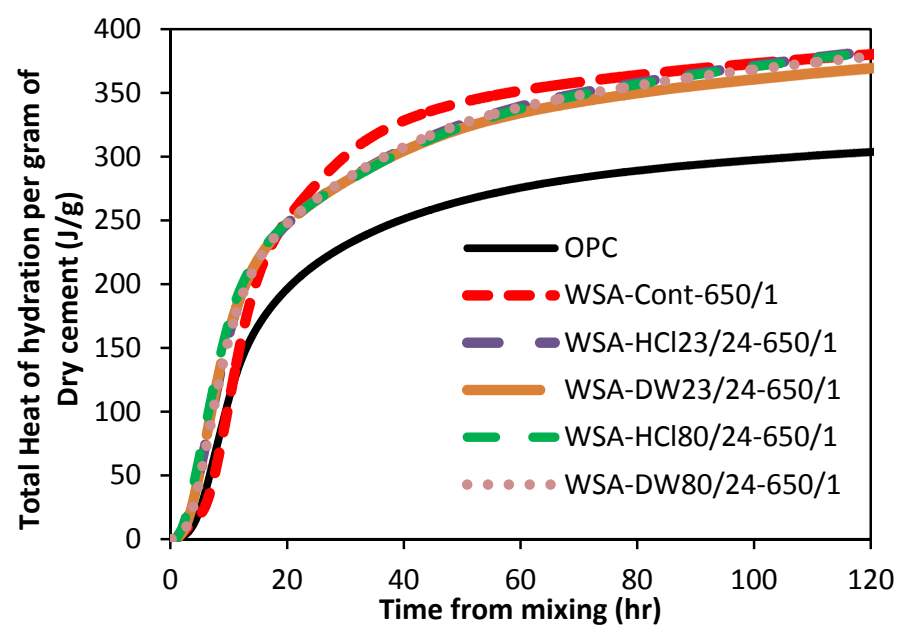

472 Figure 13: Total heat of hydration of paste samples containing different wheat straw ash

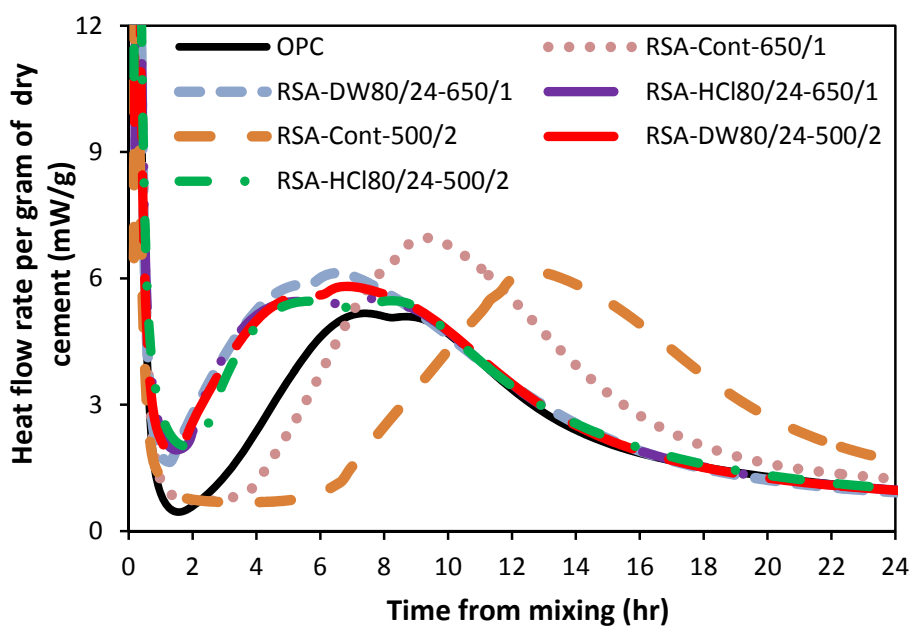

Figure 14: Heat evolution rate of paste samples with and without rice straw ash

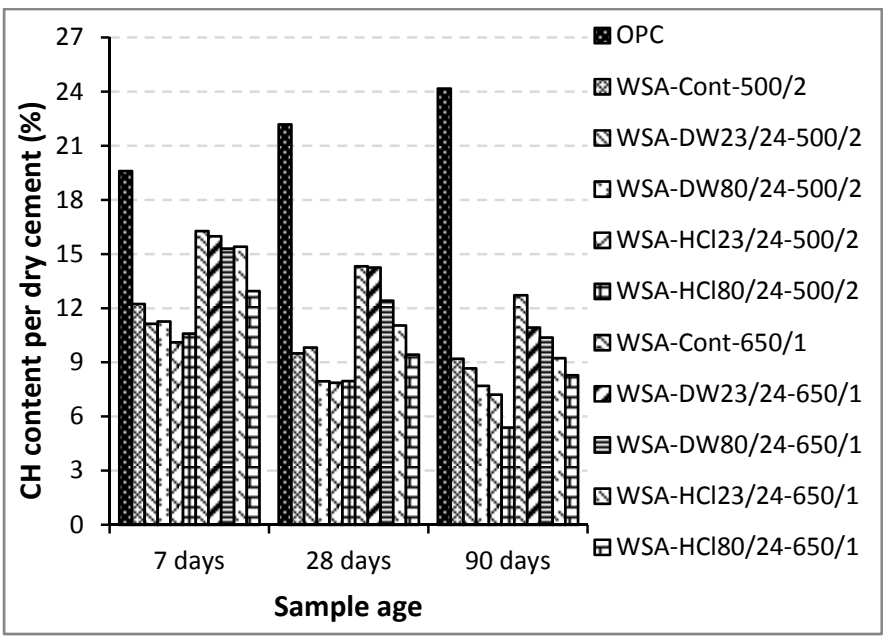

Figure 15: CH content of cement paste containing wheat straw ash 


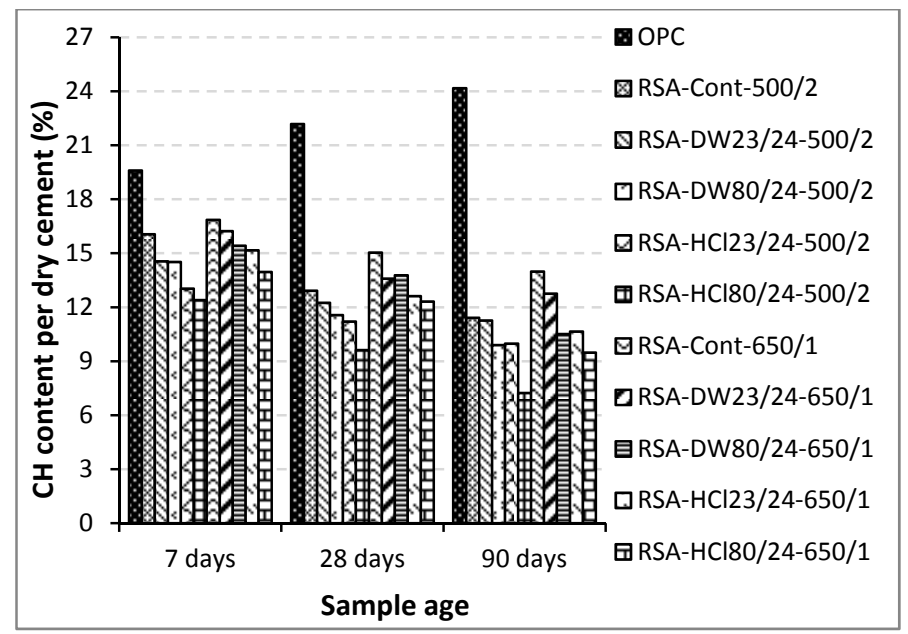

Figure 16: $\mathrm{CH}$ content of cement paste containing rice straw ash

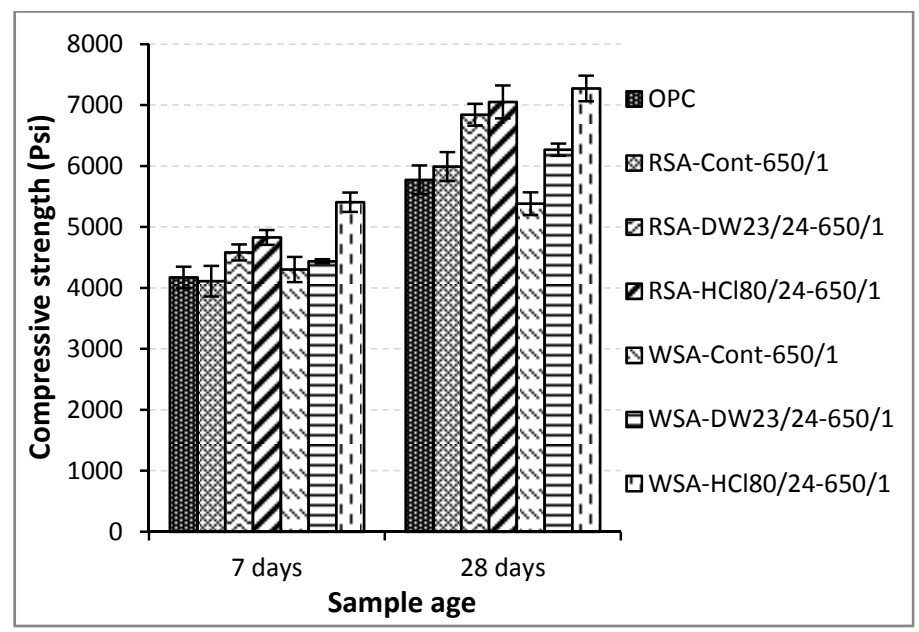

Figure 17: Mortar cube compressive strength data

a)

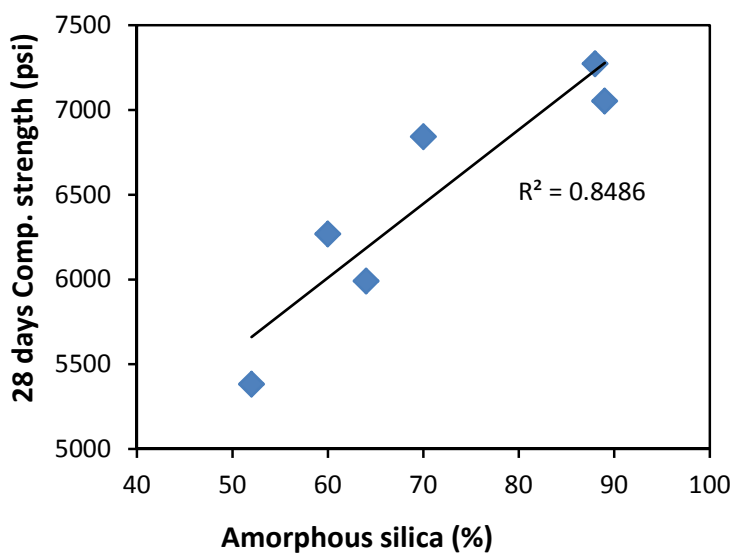


b)
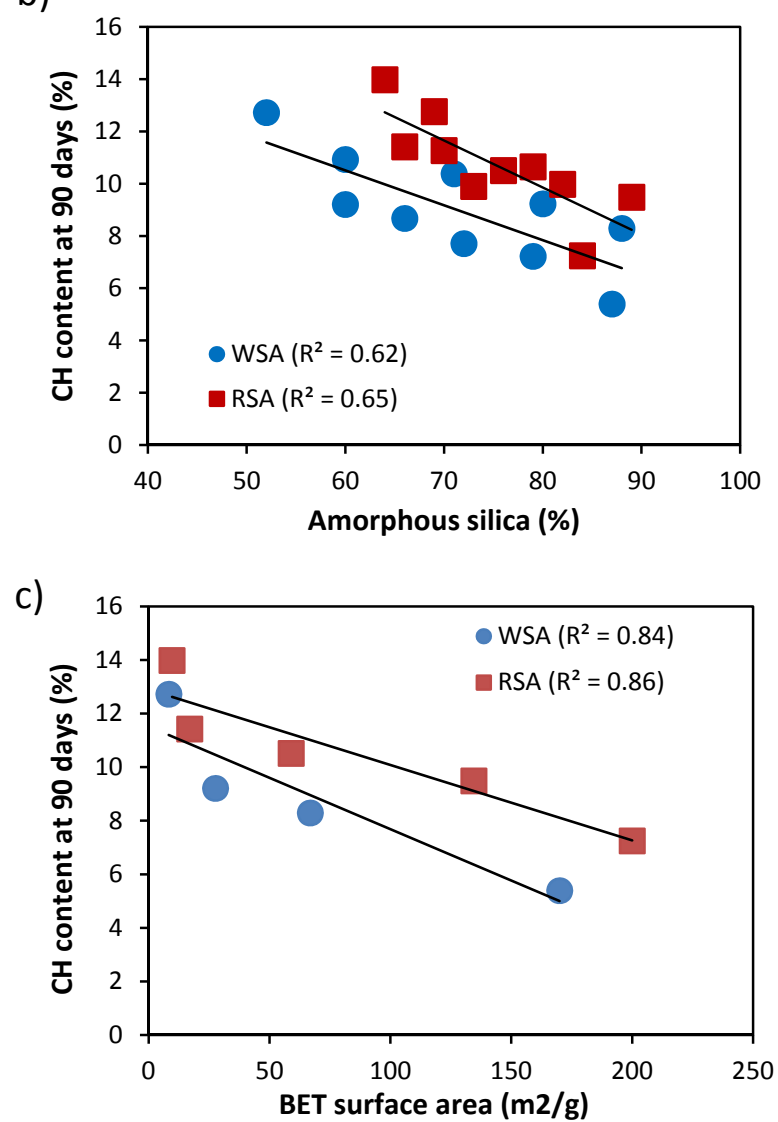

Figure 18: Relation between material characteristics and performance a) amorphous silica content vs 28 days mortar cub strength, b) amorphous silica content vs $\mathrm{CH}$ content of paste after 90 days c) Surface area of ash vs $\mathrm{CH}$ content of paste after 90 days 